\title{
Lumen
}

Selected Proceedings from the Canadian Society for Eighteenth-Century Studies

\section{Eugenia's Escape: The Written Word in Frances Burney's Camilla}

\section{Diane Harris}

Volume 17, 1998

Theatre of the world

Théâtre du monde

URI : https://id.erudit.org/iderudit/1012386ar

DOI : https://doi.org/10.7202/1012386ar

Aller au sommaire du numéro

Éditeur(s)

Canadian Society for Eighteenth-Century Studies / Société canadienne d'étude du dix-huitième siècle

ISSN

1209-3696 (imprimé)

1927-8284 (numérique)

Découvrir la revue

Citer cet article

Harris, D. (1998). Eugenia's Escape: The Written Word in Frances Burney's Camilla. Lumen, 17, 151-164. https://doi.org/10.7202/1012386ar

Copyright (c) Canadian Society for Eighteenth-Century Studies / Sociéte canadienne d'étude du dix-huitième siècle, 1998
Ce document est protégé par la loi sur le droit d'auteur. L'utilisation des services d'Érudit (y compris la reproduction) est assujettie à sa politique d'utilisation que vous pouvez consulter en ligne.

https://apropos.erudit.org/fr/usagers/politique-dutilisation/ 


\section{Eugenia's Escape: The Written Word in Frances Burney's Camilla}

The idea of creating an ugly heroine held a durable fascination for Frances Burney. Margaret Doody notes that she toyed with the idea when planning the novel which became Cecilia: '[a]t some point, the heroine of the new novel was apparently to be an "unbeautiful, clever heroine, beset all round for the sake of her great fortune". ${ }^{11}$ The heroine of The Wanderer is initially described as an ugly Creole, her lovely features daubed with blackface. However, Burney relegates to a sub-plot her most sustained exploration of the ugly woman's plight. Although Camilla's eponymous heroine is as beautiful as the conventional novel reader could wish, her little sister Eugenia is grievously deformed and, unlike the Wanderer's, her ugliness cannot be cured with soap and water. Some of Camilla's most moving passages deal with the pain the delightful Eugenia knows at being trapped in a repulsive body. Yet Eugenia's story is no tragedy, for Burney - a century before Cyrano de Bergerac - suggests that the written word can prove the salvation of an uncomely individual. After enduring her uncle's clumsy attempts to reshape her reality through language, Eugenia creates for herself a textual body which reflects her inner beauty in a way that her misshapen physical body cannot.

Camilla tells the story of the family of Mr. Tyrold, an admirable rector who has three daughters, Lavinia, Camilla and Eugenia, and one son, Lionel. It becomes apparent early in the novel that Camilla Tyrold and Edgar Mandlebert, an orphan living on a nearby estate, are deeply in love. Mr. and Mrs. Tyrold have always cherished the idea of this match. If Camilla runs to some thousand pages, it is only because the two lovers are discouraged from communicating in a free and spontaneous manner. Edgar's tutor counsels him against revealing his love so that he may observe Camilla to ensure that she would make an ideal mate before proposing marriage. Camilla is muted more radically, her father impressing on her that her very femininity will be undermined if she reveals her love before being assured of Edgar's. As Julia Epstein notes, Burney's third novel is the story of a silencing: 'Camilla tells the story of 
love postponed, thwarted, frustrated, misled, and deliberately unspoken and even disguised. ${ }^{2}$ Elisabeth Rose Gruner notes the work's curiously static quality when she calls Camilla' a courtship novel without suspense, a bildungsroman without visible growth. ${ }^{3}$

Camilla's story highlights the nefarious consequences of the fact that correct female behaviour in the eighteenth century entails stifling a woman's inner self. In Camilla's sub-plot, Eugenia is silenced even more cruelly than her sister; her inner self is less accessible because her physical appearance has been tampered with. The two elder Tyrold girls are exceptionally lovely, and this external beauty is seen as the outward manifestation of their inner natures. Having described Lavinia's serenely exquisite features, the narrator declares she need hardly depict her character, for ' $[\mathrm{t}]$ he form and the mind of Lavinia were in the most perfect harmony. ${ }^{\prime 4}$ Camilla's winsome, captivating features similarly reveal her inner nature: 'Her form and her mind were of equal elasticity' (15). When displeased by a perceived flaw in Camilla's behaviour, Edgar is time and again softened by the expressive play of her features. Although the little Eugenia is born even more beautiful than her older sisters, a series of accidents will shatter the perfect correspondence of inner and outer loveliness. Unlike her sisters,' Eugenia's face is no text on which the observer can read her inmost self.

Julia Epstein notes that the Tyrold daughters are 'the only young women in Burney's novels to be raised in a traditional nuclear family with a mother as well as a father. ${ }^{5}$ However, Eugenia's parents fail to shield her from a seemingly innocuous member of the extended family. The man responsible for deforming her is the baronet Sir Hugh, Mr. Tyrold's unmarried older brother. Although rich, Sir Hugh lacks Mr. Tyrold's education and judgment. His great passion is the sporting life, but when gout and a riding accident leave him lame, he decides to cultivate the pleasures of family. Sir Hugh moves nearer his younger brother and, seeing him surrounded by his children, comes to regret the course of his life: 'a severe self-upbraiding followed his view of the happiness of his brother; he regretted he had not married at the same age, that he might have owned as fine a family' (11). He establishes a close relationship with his nieces, and this avowedly benign avuncular interest will destroy Eugenia's loveliness.

The day which marks Eugenia's descent into grotesqueness begins under the sign of great merriment as the children gather at Sir Hugh's to celebrate Camilla's birthday. Sir Hugh suffers his beloved Camilla 'to govern and direct him at her pleasure' (18), and she entertains herself by turning him into a grotesque female: 'She metamorphosed him into a female, accoutring him with her fine new cap ... and then, tying the maid's apron round his waist, put a rattle into his hand, and Eugenia's 
doll upon his lap, which she told him was a baby that he must nurse and amuse' (18). He is turned into a female; since he has Eugenia's doll on his lap, we can see him as a travesty of Eugenia. Significantly, this grotesque Eugenia becomes an object of ridicule, universally stared at and laughed at:

The excess of merriment thus excited spread through the whole house. Lionel called in the servants to see this comical sight, and the servants indulged their numerous guests with a peep at it from the windows. Sir Hugh, meanwhile, resolved to object to nothing, performed every part assigned him, joined in their hearty laughs at the grotesque figure they made of him. (18)

A grotesque, wealthy and lame Eugenia who is the object of stares and ridicule: the image is to become relevant within the next few pages of the novel. After being turned into a hideous version of his youngest niece, Sir Hugh will proceed to reshape Eugenia according to this grotesque caricature.

Sir Hugh unwittingly destroys Eugenia's beauty in two stages. First, he shows poor judgment in bringing her to a crowded fair. Since Mrs. Tyrold has deemed Eugenia too frail to be inoculated against smallpox, the consequences are grave: the little girl catches the disease and is severely scarred. Next, Sir Hugh is responsible for Eugenia's being lamed in a fall from a teeter-totter. Grief-stricken at the damage he has wrought, Sir Hugh disinherits Camilla to make a will in his youngest niece's favour. In so doing, he completes his remaking of Eugenia in his own image: she too is risible, infirm, and rich. Sir Hugh had lamented his lack of offspring, and in a macabre fashion, his destruction of Eugenia's beauty remedies this lack. After her accidents, Eugenia will henceforth live with him as his acknowledged heiress. This is only fitting, for a curious family resemblance has sprung up between the two. Eugenia is less flesh of his grotesque flesh than of his grotesque mind; her physical self has become an embodiment of the disorder and incapacity within him.

Camilla's experience suggests how difficult it is even for a woman graced with every exterior charm to find romantic fulfilment. How then is Eugenia - short, misshapen, lame and scarred - to reach happiness? Part of the answer lies in Burney's subversion of the logocentric tradition. In De la Grammatologie, Jacques Derrida traces the tenacious prejudice against writing which derives from its association with absence. If the spoken word replaces the idea or thought, the written word, which replaces the spoken word, is at two removes from the idea. The spoken word implies plenitude and origin, while the written word, a mere sign of the sign, is inscribed in the logic of reduplication and supplementarity: 
'l'écriture est le supplément par excellence puisqu'elle marque le point où le supplément se donne comme supplément de supplément, signe de signe, tenant lieu d'une parole déjà signifiante. ${ }^{6}$ Yet if the written word is generally denigrated because it implies the absence of the communicator's person, certain authors - Frances Burney among them - value it for precisely the same reason.

Before turning to Burney, we will briefly consider the example of Cyrano de Bergerac, for Edmond Rostand treats in stylized form the theme of writing as an escape from the grotesque body. Painfully conscious of his physical deformity, Cyrano cannot tell Roxane of his love. The play explores various solutions. Cyrano seizes the opportunity of speaking through the body of another man: 'Tu marcheras, j'irai dans l'ombre à ton côté: / Je serai ton esprit, tu seras ma beauté,' he says to the handsome Christian. ${ }^{7}$ Then, as he addresses Roxane in the darkness from beneath her balcony, Cyrano knows the intoxication of speaking himself in circumstances which elide the body altogether: 'Laissez un peu que l'on profite ... / De cette occasion qui s'offre ... de pouvoir / Se parler doucement sans se voir' (III.7.1391-3). For a moment Cyrano experiences the pleasure of speaking to Roxane without the impediment of his detested body. Yet this scene ultimately confirms that the body is an integral part of conversation. Stirred by Cyrano's words, Roxane desires contact with the body, and Christian claims the kiss which Cyrano's eloquence has won.

The balcony scene underscores what Cyrano knew already - that it is artificial and difficult to eliminate the body from conversation. He had tried to do precisely this by instituting a linguistic reshaping of reality. Though unable to change his reflection in the mirror, Cyrano attempts to ensure that his appearance will never be reflected back to him in the mirror of language. Cyrano's cadets warn the newly-recruited Christian that he must observe a strict linguistic code: 'Monsieur de Neuvillette, apprenez quelque chose: / C'est qu'il est un objet, chez nous, dont on ne cause' (II.9.1048-9). Pronouncing the word 'nez' in Cyrano's presence is a powerful speech act whose punishment will be swift and terrible. Yet this attempt to eliminate the body from conversation proves futile. The interdiction makes Cyrano's entourage all the more aware of his nose, and Cyrano is helpless when Christian decides to mock his deformity in public (II.9).

The linguistic interdiction fails, and situations - such as the balcony scene - which permit Cyrano to eliminate his body from conversation are rare and ephemeral. The possibility of bodiless conversation remains the stuff of fantasy. It is the written medium which offers Cyrano a reliable escape from the body he finds so repulsive. He is able to express and inspire love through the letters he writes to Roxane under Chris- 
tian's name. Revealingly, Roxane sees the letters as the prolongation of the bodiless communication of the balcony scene:

Mon Dieu, je t'adorais, c'est vrai, depuis qu'un soir,

D'une voix que je t'ignorais, sous ma fenêtre,

Ton âme commença de se faire connaître ...

Eh bien! tes lettres, c'est, vois-tu, depuis un mois,

Comme si tout le temps, je l'entendais, ta voix

De ce soir-là, si tendre, et qui vous enveloppe! (IV.8.2100-5)

The final act confirms the link between the written word, and the magical experience of bodiless conversation. On the day of his death, Cyrano reads aloud to Roxane one of the letters supposedly penned by Christian. For Roxane, the moment of recognition occurs as it grows dark. It is as the night obscures Cyrano's physical form, turning him into disembodied voice, that she finally recognizes him.

Frances Burney anticipates Rostand in exploring the agony of being trapped in a grotesque body and in suggesting that the written medium offers an escape. Eugenia's predicament is even greater than Cyrano's by virtue of the fact that she is an eighteenth-century woman. As Camilla's main plot suggests, society strictly constrains a woman's freedom to communicate, and these constraints are superadded to those already experienced by the grotesque individual. In Camilla, Burney first depicts the attempts of a male - Sir Hugh - to use language to reshape reality on Eugenia's behalf. After the failure of this project, Burney explores Eugenia's own attempts to form a textual body which will modify reactions to her unpleasing physical body.

Stricken with guilt over his unintentional disfigurement of his niece, Sir Hugh seeks to make her some kind of compensation. At first, he suggests that his own body be destroyed as fitting punishment: ' $O$ brother! O sister! why don't you both kill me in return?' (29). This extreme solution is rejected, and instead Sir Hugh puts into operation a three-fold linguistic strategy for dealing with Eugenia's deformity.

The first element of Sir Hugh's strategy is to make a new will leaving all his fortune to Eugenia. He hopes that the attraction of money will make up for Eugenia's disfigurement: 'a guinea for every pit in that poor face will I settle on her out of hand' (30). Here the written word is a supplément in quite literal fashion. Yet it is a supplement not for spoken language, as in the mainstream logocentric tradition, but for the physical body: the new will is designed to supplement and compensate for the deficiencies of Eugenia's person. We learn too that the will is 'properly signed and sealed' (32) - sealed to protect its integrity, just as Eugenia's own body should have been sealed and protected from the harm the 
outside world can inflict. The will's immediate consequences suggest that text can remould body, at least for the will's author: '[Sir Hugh] could now bear to look at the change for the worse in Eugenia, without finding his heart-strings ready to burst at the sight' (32).

The second element of the linguistic strategy has a close parallel in Cyrano de Bergerac. If Cyrano forbids his entourage to allude to his nose, Sir Hugh similarly insists that Eugenia's deformities never be mentioned:

Those incidents, therefore, from never being named, glided imperceptibly from her thoughts; and she grew up as unconscious as she was innocent, that, though born with a beauty which surpassed that of her lovely sisters, disease and accident had robbed her of that charm ere she knew she possessed it. (50)

The guilt-ridden uncle tries to reshape the reality of Eugenia's body through a linguistic conspiracy. When Edgar is reintroduced into the family, Sir Hugh 'begged, in a whisper, that he would not seem to notice the ugliness of Eugenia, which, he said, was never mentioned in her hearing, by his particular order' (56). Sir Hugh chastizes a servant who merely reports the insults of another: 'I won't have my niece called ugly, Jacob! you know it's against my commands such a thing's being mentioned' (203).

Sir Hugh strictly regulates the spoken word, as though believing that bodily deformities do not truly exist if never voiced. He apparently succeeds. At the Tyrold girls' first ball, Edgar expresses surprise when Camilla says she wishes someone would ask Eugenia to dance. 'You don't think she would dance?' (64), he asks, to which Camilla replies: 'O yes she would! her lameness is no impediment; for she never thinks of it' $^{\prime}(64)$. The handicaps which are never mentioned trouble Eugenia little. To an extent, the linguistic conspiracy protects Eugenia even when she comes into contact with strangers. At the ball, she remains oblivious to the 'impertinent witticisms' to which her appearance gives rise: 'She was shielded, however, herself, from all undeserved mortifications, by not suspecting any were meant for her' (61). Sir Hugh has bequeathed to Eugenia not only his fortune, but also his imperfect grasp of the world around him.

Sir Hugh's third linguistic strategy, less consciously planned than the first two, is a kind of bibliotherapy in which the written word is again called upon to compensate for the deficiencies of the body. In this strategy, Sir Hugh once again appears as a grotesque Eugenia before our attention is turned to Eugenia herself. Compelled by his infirmities to lead a sedentary life, Sir Hugh begins to envy his learned brother, to 
regret his neglect of studies in his youth, and finally to think that he could yet find consolation in the world of books:

In the midst of the acute anguish, and useless repentance, which now alternately ravaged his happiness, it suddenly occurred to him, that, perhaps, with proper instruction, he might even yet obtain a sufficient portion of this enviable knowledge, to enable him to pass his evenings with some similarity to his brother. (34)

Once again, the written word is envisaged as a kind of supplement to the defective body: 'if I could only learn just enough to amuse me at odd hours, and make me forget the gout, it's as much as I desire' (34-5), says Sir Hugh. Camilla's parents are skeptical of the bibliotherapy Sir Hugh plans for himself, and as usual, Camilla's mother is the more cutting of the two: 'Mrs. Tyrold treated this scheme with calm, but complete contempt' (35). Her contempt proves justified. Far from consoling him for his infirmities, the rigours of Greek and Latin verbs exacerbate Sir Hugh's ill health: 'His nights became infected by the perturbation of the day; his health visibly suffered from the restlessness of both, and all his flattering hopes of new and unknown happiness were ere long exchanged for despair' (39).

The project of bibliotherapy does more than provoke laughter at Sir Hugh's naïveté, for Burney again presents Sir Hugh as a grotesque version of Eugenia in order to anticipate a new development in the young girl's story. Sir Hugh renounces his project of learning, but is reluctant to deprive his tutor, Dr. Orkborne, of his livelihood. After several fruitless projects, he hits on the plan of employing Orkborne to educate Eugenia. The idea which had seemed absurd and grotesque in Sir Hugh's case - text as compensation for bodily deficiencies - seems plausible when applied to Eugenia: 'The little girl, who was naturally of a thoughtful turn, and whose state of health deprived her of most childish amusements, was well contented with the arrangement (49). Bibliotherapy soon provides the richest of consolations: 'She had now acquired a decided taste for study, which, however unusual for her age, most fortunately rescued from weariness or sadness the sedentary life, which a weak state of health compelled her to lead' (50).

Although successful in the short term, Sir Hugh's compensatory strategies prove harmful as Eugenia becomes a young woman. She falls prey to Bellamy, a debt-ridden rake after her fortune. Left naïve and idealistic by her education, she cannot recognize the crass motives behind her suitor's declarations of love: 'what she had gathered upon such subjects in the poetry and history she had studied with Dr. Orkborne, had only impressed her fancy in proportion as love bore the character of heroism, and the lover that of an hero' (315). Sir Hugh has 
provided Eugenia with the classical education thought to develop judgment and reason in boys. Ironically, however, she would have been better able to see through Bellamy had she indulged in more stereotypically female readings: 'Having read no novels, her imagination had never been awakened to scenes of this kind' (315). Eugenia has been kept from a wide variety of acquaintances, both human and literary.

Sir Hugh's linguistic conspiracy also proves harmful to his niece. After a peaceful childhood spent among her books and her family, Eugenia inevitably comes up against a world which knows nothing of the verbal taboos with which Sir Hugh has surrounded her. Here the boorish Mr. Dubster plays a key role. Despite Lionel's irritating machinations, there is never any danger that he will marry Camilla. Dubster poses a threat of a different sort, however, for his linguistic frankness menaces the fragile status quo Sir Hugh has established. He does only mild damage when he refers to Eugenia as 'that limping little body' (85) or as 'the little lame duck'(91). He does more serious harm when he asks her openly about the cause of her deformities:

"Pray, ma'am," he continued, "was it a fall or was you born so?"

Eugenia looked struck and surprized; and Camilla hastily whispered it was a fall, and bid him say no more about it; but, not understanding her, "I take it, then," he said, "that was what stinted your growth so, Miss? for, I take it, you're not much above the dwarf as they shew at Exeter Change? Much of a muchness, I guess. Did you ever see him, ma'am?"

"No, sir,"

"It would be a good sight enough to see you together. He'd think himself a man in a minute. You must have had the small pox mortal bad, ma'am. I suppose you'd the conflint sort?" (280)

At this speech Eugenia is 'much disconcerted' (280), but there is worse to come. Dubster exposes her to several lower-class women who taunt her about her appearance. It becomes apparent that Eugenia's loved ones have done her a disservice in trying to shield her. When the women's comments make Eugenia cruelly aware of her grotesqueness, she reproaches her family with quiet dignity:

'These women,' said she, calmly, 'are not to blame; they have been untutored, but not false; and they have only uttered such truths as I ought to have learnt from my cradle. My own blindness has been infatuated; but it sprung from inattention and ignorance. It is now removed!' $(294)^{8}$

Eugenia shares with her father her retrospective shock at the deficiencies of her education: "'Was my Mother, then, Sir," said she, reproach- 
fully, "unapprized of the worldly darkness in which I have been brought up? Is she unacquainted that a little knowledge of books and languages is what alone I have been taught?"' (301). Her bookish education will prove a liability in more ways than one. Richardson's Sir Charles Grandison hints that extensive education can be detrimental to a woman's happiness. Asked if she knows anything of Greek and Latin, Harriet Byron replies, 'Who, I, a woman, know any thing of Latin and Greek! I know but one Lady who is mistress of both; and she finds herself so much an owl among the birds, that she wants of all things to be thought to have unlearned them. ${ }^{9}$ Though with a more satiric thrust, Burney similarly suggests that the learned woman - Eugenia, and before her Evelina's Mrs. Selwyn - is generally seen as an unfeminine freak.

Sir Hugh had consciously planned to educate Eugenia like a male: 'I intend to bid [Orkborne] teach her just like a man, which, as she's so young, may be done from the beginning, the same as if she was a boy' (48). Dr. Orkborne comes to think of his gifted pupil as a 'partial exception' (140) to her frivolous sex. However, the extent to which her learning has made her a grotesque, phallic creature does not become evident until she meets her prospective husband, Clermont Lynmere.

Sir Hugh has long intended that Eugenia should marry Clermont, a ward of his who lost his bequest when the baronet remade his will in Eugenia's favour. When Clermont returns from his travels, he is shocked by the appearance of his intended bride. In spite of distaste for the woman he refers to as 'that wizen little stump' (569), he does not reject her outright, for Eugenia's fortune exerts a powerful attraction; Sir Hugh's decision to compensate for her bodily deficiencies by making her his heiress is apparently effective. Ironically, it is another of Sir Hugh's compensatory strategies which makes Clermont repudiate his wealthy intended, for he believes Eugenia to have been made more monstrous by her learning than by her physical accidents. Finding that Sir Hugh has 'had her brought up in the style of a boy,' Clermont exclaims, 'what have I to do with marrying a girl like a boy?' (592) Clermont's conviction that Eugenia's learning is 'worse than her ugliness' (579) is all too common, as we learn when Miss Margland spitefully spreads word of Eugenia's education:

But another rumour got abroad, that soon entirely cleared Eugenia, not merely of lovers but acquaintances; namely, her studies with Dr. Orkborne ... This, shortly, made Eugenia stared at still more than her peculiar appearance. The misses, in tittering, ran away from the learned lady; the beaux contemptuously sneering, rejoiced she was too ugly to take in any poor fellow to marry her. (748) 
Sir Hugh has apparently ruined Eugenia's chances of marriage. Just as he was responsible for turning her into a physical monster through the accidents he occasioned, so is he responsible for turning her into a mental monster through the education he has given her. Indeed, rumour has it that her very physical deformities are the result of her education: 'Some imagined her studies had stinted her growth; and all were convinced her education had made her such a fright' (748).

After an initial measure of success, Sir Hugh's triple linguistic strategy proves a source of pain and suffering to Eugenia. Yet it would be hasty to conclude that language is powerless to remedy the body's misfortunes, for Burney is once again presenting Sir Hugh as a grotesque caricature of his niece before turning our attention to the dignified figure of Eugenia herself. After Sir Hugh's clumsy attempts to reshape her reality through language, Eugenia will find happiness by using language to sculpt her own identity.

Although Mr. Dubster had suggested the Exeter Change dwarf as a fit partner for Eugenia, the young woman herself has other ideas. She falls in love with an unusually handsome man, just as her male counterpart Cyrano falls in love with an unusually beautiful woman. Eugenia's situation seems doubly hopeless by virtue of the fact that Melmond, the man she loves, is exceptionally sensitive to physical beauty; his intense infatuation with Indiana can have no other cause. How can the frightful Eugenia win out over the stunning Indiana? Like Cyrano, Eugenia discovers that the written word permits her to communicate the beauty of her soul in the absence of her unsightly body.

In his analysis of the logocentric prejudice against the written word, Jacques Derrida notes that writing is aligned with body in the body/soul split: 'l'écriture, la lettre, l'inscription sensible ont toujours été considérées par la tradition occidentale comme le corps et la matière extérieurs à l'esprit, au souffle, au verbe et au logos' (De la Grammatologie 52). The corporeality of written text in part explains the denigration of writing in Western culture. Yet it is precisely this feature of the written word which proves useful to both Eugenia and Cyrano. The logocentric tradition views writing as a substitute for the spoken word. However, because the text is a physical body, another substitution becomes possible: the text can stand in not for the spoken word, but for the physical form of the individual who wishes to communicate. Cyrano de Bergerac and Camilla are faithful to the logocentric tradition insofar as they conceive of the spoken word as a substitute or supplément. They skew logocentric logic insofar as they see the written word as a substitute not for the spoken word, but rather for the body of the speaker.

Like Cyrano's, Eugenia's hope lies in the fact that her texts can function in the absence of her body. In fact, they can even operate in the 
absence of a desire to communicate. Melmond first glimpses the beauty of Eugenia's soul when he sees a poem in which she expresses her love for him. However, he is shocked by the thought that she would permit anyone to see this tender confession of love: "Why, my sister," he cried, "why would she give you this? why would you deliver it?"' (675). Melmond's sister hastens to the defense of Eugenia's female reticence:

My brother, my dear brother, this matchless creature merits not so degrading an idea; she gave me not the precious paper ... she knows not I possess it; it was found upon the stairs: Ah! far from thus openly confessing her unhappy prepossession, she conceals it from every human being; even her beloved sister, I am convinced, is untrusted; upon paper only she has breathed it, and breathed it as you see ... with a generosity of soul that is equal to the delicacy of her conduct. (675)

The written word is ideally suited to Cyrano because it can function in the absence of his physical form. The written word is ideally suited to Eugenia for a second reason as well: it can function in the absence of her intention to communicate. ${ }^{10}$

Possessed of great literary sensitivity, Melmond is moved by Eugenia's love poem once he understands that he is seeing it against her wishes: 'Melmond now felt subdued. To have excited such a regard in a mind that seemed so highly cultivated, and so naturally elegant, could not fail to touch him; and the concluding line deeply penetrated him with tender though melancholy gratitude' (675-6). Since in any case poverty prevents him from marrying Indiana, Melmond agrees to propose to Eugenia. She is blissfully happy until events reveal to her that Indiana still possesses Melmond's heart. At this time a second text reveals the nobility of her soul. Eugenia draws up a document stating that she will give up half her fortune so that Melmond and Indiana can marry. ${ }^{11}$ This legal document completes the work that the misplaced poem had begun. Melmond recognizes that Eugenia's inner beauty is infinitely more desirable than Indiana's superficial charms: "Ah, Madam!" exclaimed Melmond, wholly overcome, "the noblest as well as softest of human hearts I perceive to be yours - and were mine at my own disposal - it must find you resistless!"' (746). Fortunately, it is not long before Indiana's infidelity places him at his own disposal, and, overcome by the beauty of Eugenia's textual body, he once again proposes to her: 'Melmond, long conscious of her worth, and disgusted with all that had rivalled it in his mind, with the fervour of sincerity, yet diffidence of shame and regret, now fearfully sought the favour he before had reluctantly received' (912). 
Before the reconciliation with Melmond, however, Eugenia lives through a period of believing that she will never inspire romantic love. Convinced that she is henceforth destined to be 'only a spectatress of others' (905), she undertakes to write her memoirs. Eugenia has already experienced one linguistic reshaping of her body: the conspiracy designed to keep her in ignorance of her grotesqueness. In embarking on her memoirs, she engages in an alternative linguistic treatment of her person. No simple object of ridicule or pity, Eugenia's body will serve to impart a 'philosophical idea' (905).

From the first sentence, Eugenia addresses the issue of her physical appearance. Hers will not be the typical memoirs of a woman. She is distinguished from other women textually, just as she is physically: 'No blooming coquette, elated with adulation and triumphant with conquest, here counts the glories of her eyes, or enumerates the train of her adorers: no beauteous prude, repines at the fatigue of admiration, nor bewails the necessity of tyranny' (905). Eugenia's literary presentation of her body gives new meaning to her personal tragedy. She transforms her face into a text which indicts society's superficial valuation of women:

$\mathrm{Ye}$, too, $\mathrm{O}$ lords of the creation, mighty men! impute not to native vanity the repining spirit with which I lament the loss of beauty; attribute not to the innate weakness of my sex, the concern I confess for my deformity; nor to feminine littleness of soul, a regret of which the true source is to be traced to your own bosoms, and springs from your own tastes: for the value you yourselves set upon external attractions, your own neglect has taught me to know; and the indifferency with which you consider all else, your own duplicity has instructed me to feel. (905)

The linguistic conspiracy initiated by Sir Hugh had sought to deny Eugenia's physical deformities, yet this erasure of the body was forced and unnatural, for the spoken word inevitably implies the presence of the body. In contrast, the written medium naturally functions in the absence of its creator. This elision of the body gives Eugenia the freedom to offer a textual interpretation of her person; through this text, she can ask people to view her physical self in a different way. A significant detail reminds us that the written word is the medium of the body's absence. In the first section of her memoirs, Eugenia leaves a blank space in which she intends to insert her portrait, yet this space remains blank at the novel's close. This blank underscores the fact that the written medium permits Eugenia to transcend the brute fact of her physical deformity, and engage instead in a textual re-presentation of her body. 
Eugenia rejects the familiar idea that a woman's face is a kind of text which reveals her inner nature. When Melmond is astonished at the generous offer of half her fortune, Eugenia rebukes him gently: 'Shew less surprise, Sir, or I shall conclude you thought me as frightful within as without! But no! Providence is too good to make the mind necessarily deformed with the body' (746). Having rejected the idea that her face is a text, Eugenia takes pen in hand to write her own texts: poems, legal documents and memoirs which reveal her inner beauty. Although unable to reshape her physical body as she would like, Eugenia uses to the full her power to create for herself a textual body deserving of love and admiration.

\section{DIANE HARRIS}

University of Toronto

\section{Endnotes}

1 Frances Burney: A Life in the Works (New Brunswick, NJ: Rutgers UP, 1987) 120.

2 The Iron Pen: Frances Burney and the Politics of Women's Writing (Madison: U of Wisconsin P, 1988) 127.

3 'The Bullfinch and the Brother: Marriage and Family in Frances Burney's Camilla,' Journal of English and Germanic Philology 93 (1994): 19.

4 Camilla, or A Picture of Youth, ed. Edward A. Bloom and Lillian D. Bloom (Oxford: Oxford UP, 1972) 223. Future references will appear within parentheses in the text.

5 Epstein 142.

6 De la Grammatologie (Paris: Les Editions de Minuit, 1967) 398.

7 Cyrano de Bergerac (Paris: Classiques Larousse, 1991) II.10.1146-7. Future references will appear within parentheses in the text.

8 This critical moment can be seen in terms of the Lacanian framework of the development of subjectivity. Eugenia has passed through the 'mirror stage,' for the strategy to keep her ignorant of her ugliness never entailed depriving her of mirrors. It is the next stage of development which she has been denied. If subjectivity is only fully achieved through language, Eugenia's development has been hindered by the artificial linguistic environment in which she has been enclosed since the loss of her beauty. Only when the uncouth women's taunts reflect back to her an image of herself does Eugenia fully acquire subjectivity, a sense of the uniqueness and distinctness of her (grotesque) 'I.' She has been kept not from physical mirrors, but from language, the ultimate mirror which shapes the sense of self. See Lacan's 'Le Stade du miroir comme formateur de la fonction du Je,' Ecrits I (Paris: Points Essais-Seuil, 1966) esp. 89-90.

9 Sir Charles Grandison, ed. Jocelyn Harris (London: Oxford University Press, 1972) $1: 49$.

10 A found text is crucial to resolving the main romantic plot as well. Camilla confesses her love to Edgar in a note on which she inscribes, 'Not to be delivered till 


\section{Diane Harris}

I am dead' (870). The letter happily comes to Edgar's eyes, and all his doubts are removed 'by learning thus the true feelings of her heart, as depicted at the awful crisis of expected dissolution' (898). Like Eugenia, Camilla communicates her feelings to her beloved, but is simultaneously absolved of any unwomanly intention to communicate - at least during her lifetime.

11 This episode is perhaps inspired by Rousseau's La Nouvelle Héloïse, in which Lord Bomstom offers to give up one third, or even one half of his fortune so that his friend St-Preux will be able to marry Julie. Yet it is Burney's own innovation to have this generous gesture made in the form of the written word. 